\title{
Thyroiditis in Mosul: a clinico-pathological study
}

\author{
Ahmad F. Lazim* Bedoor AK. Al-Irhayim** \\ *Al-Jamhory Teaching Hospital-Mosul; **Department of pathology. College of Medicine, University of \\ Mosul.
}

(Ann. Coll. Med. Mosul 2008; 34(2): 167-175).

Received: $13^{\text {th }}$ April 2008; Accepted: $5^{\text {th }}$ Nov 2008.

\begin{abstract}
Objective: To estimate the relative frequency, as well as specific pathological features of thyroiditis in thyroidectomy specimens in Mosul.

Methods: One hundred (100) cases of histopathologically proved thyroiditis had been evaluated between July 2001 and March 2002. Histopathological examination, serum autoantibody assay, with thyroglobulin immuno-histochemical marker were done. In addition we utilized results of thyroid function tests brought by many patients

Results: Hashimoto's thyroiditis (H.T), 31 cases, F:M ratio 30:1, median age 38 years. Eighty percent of the cases were euthyroid. Focal lymphocytic thyroiditis (FLT) was recognized in 66 cases. It was divided into three grades according to the intensity of the lymphocytic infiltration, all cases showed female preponderance with F:M ratios of 9:1, 23:1 and 1:1 for grades I,II and III respectively with a mean age of 37 years. H.T. and FLT shared positivity for serum autoantibody and the presence of other pathological conditions of the thyroid, namely follicular adenoma, Hurthle cell(H.C.) adenoma and papillary carcinoma. Immunohistochemical stain for thyroglobulin monoclonal antibody marker showed strong reactivity within the atrophic follicles in H.T..The remaining three cases include granulomatous, suppurative and Riedel's types of thyroiditis.

Conclusions: Thyroiditis is a common condition in Mosul with marked female preponderance, and incidence in adulthood. The two main types encountered were H.T and FLT . Hashimoto's thyroiditis invariably shows Hürthle cell metaplasia either in focal or diffuse pattern of growth, particularly the latter. While H.C., if present, are mainly sporadic in FLT. In H.T., thyroid function is related to the type of follicular epithelial cells and the presence or absence of plasma cells.
\end{abstract}

\section{الخلاصة:}

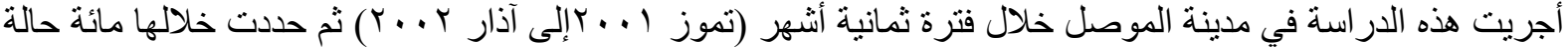

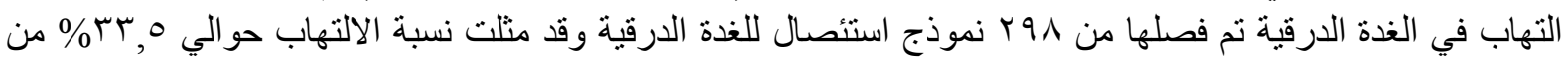

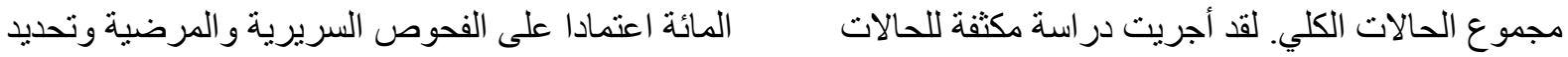
الحالة الوظيفية للغدة الدرقية وكذلك فحوصات إضافية شملت وجود الأجسام المضادة في مصل الدام، كذلك فحوصات التات مناعية كيمياوية ونسيجية على المقاطع النسيجية.

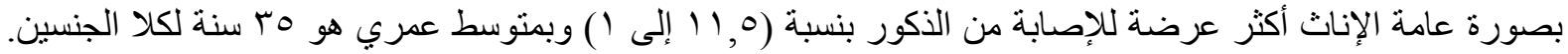

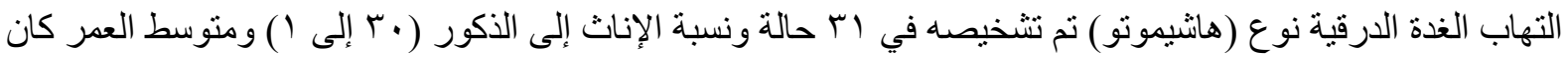

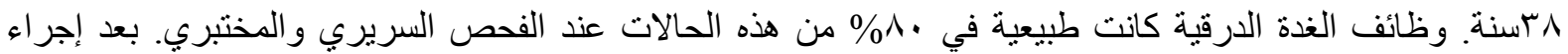

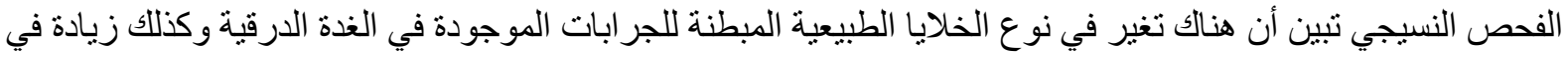

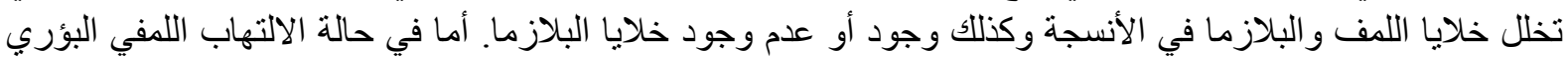

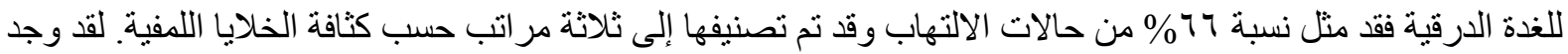




$$
\begin{aligned}
& \text { أن هنالك غلبة الإناث على الذكور فيما يتعلق بنسبة الإصابة بالمرض وحسب الصنف (9 إلى ( ) و (rr إلى ( ) و (1 إلى الصى }
\end{aligned}
$$

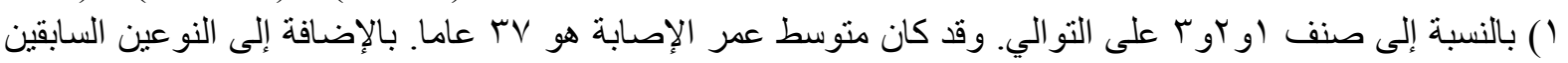

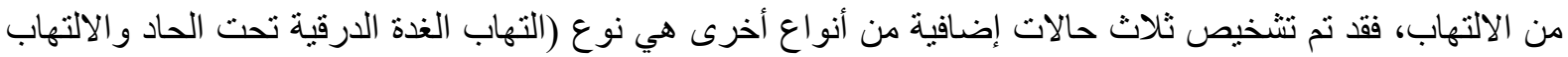

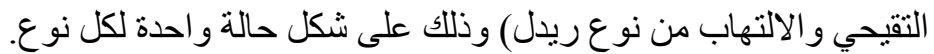

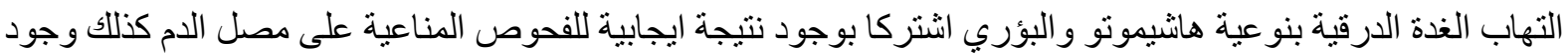

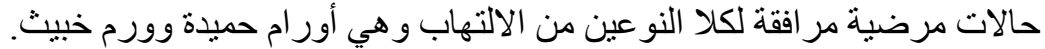

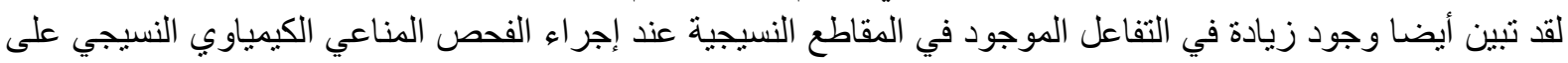

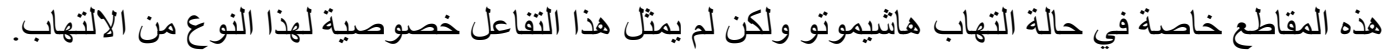

$\mathrm{T}$ hyroiditis encompasses a group of disorders that includes not only the process of clear cut inflammatory nature, but also lesions of uncertain significance, in which sclerosis and lymphocytic infiltrates are the most relevant pathologic findings ${ }^{(1)}$. Traditionally it embraces the following types:-

1. Acute thyroiditis (infectious and non infectious thyroiditides )

2. Subacute thyroiditis (DeQuervain's or granulomatous thyroiditis) ,manifested with multinucleated colloid containing intrafollicular giant cells.

3. Other granulomatous inflammations; which include; palpation thyroiditis; tuberculosis; sarcoidosis; mycoses; postoperative necrotizing granuloma, histiocytic granulomatous inflammation around haemorrhage; granulomatus vasculitis; syphilis; malakoplakia; and intrathyroidal dendritic cells, epithelioid cells and giant cells in lodine deficient goitre.

4. Autoimmune thyroiditis: it includes; Hashimoto's thyroiditis(Hurthle cell metaplasia, germinal lymphoid follicles and fibrosis; focal lymphocytic thyroiditis; atrophic thyroiditis; juvenile chronic lymphocytic thyroiditis; postpartum thyroiditis; and painless or silent thyroiditis.

5. Riedel's thyroiditis, microscopically presented as extensively hyalinized fibrous tissue completely replaces the area of the gland involved ${ }^{(2-6)}$.

The major objectives of this study are to find out the relative frequency of thyroiditis in thyroidectomy specimens in Mosul, the age and gender distribution of cases with thyroiditis, the specific pathological features of various types of thyroiditis, as well as the clinicopathological correlation of thyroiditis utilizing additional methods of investigations.

\section{Patients and Methods}

A prospective study was performed during an eight months period from July 2001 - March 2002; thyroidectomy or lobectomy was performed on 298 patients presented with goitre to the surgical departments of Al-(Jamhory) Teaching Hospital, Salam General Hospital and AL-Zahrawi Private Hospital in Mosul city.

The patients comprised 264 women and 34 men with a mean age of 34 years (age range from 15 to 60 years). One hundred (100) cases of histopathologically proved thyroiditis were segregated for this study. Those included 92 females and 8 males with a mean age of 35 years.

For a selected number of cases, the following tests were performed:-

I. Qualitative assay of circulating thyroid autoantibodies (anti-Tg and anti-TPO) in 39 patients, AMA and ANA for 35 patients. The tested sera were from patients with thyroid disorders in general, and carried out by using special kits and ELISA. The degree of lymphocytic infiltration in FLT, was graded 13 according to the number of lymphocytic foci ${ }^{(2,7)}$.

II. Immunohistochemical technique:

Avidin-biotin peroxidase complex immunohistochemical technique was available in limited amount that allowed performing it in 12 cases of thyroiditis only, using deparaffinized sections for the detection of thyroglobulin antigen by utilizing thyroglobulin monoclonal antibody marker.

III. Thyroid function tests were available preoperatively for 35 cases (35\%), which include serum T3 T4, and TSH concentrations. 


\section{Results:}

Table(1) summarizes the histologic types of thyroiditis and their gender distribution.

Table(2) demonstrates the associated conditions recognized in 5 cases of H.T. (16\%) and 11 cases of FLT (16\%).

\section{Clinico pathological correlation of thyroiditis;}

Hashimoto's thyroiditis: Table(3) demonstrates the correlation between the different histological parameters adopted in this study and the function of the thyroid as stated clinically or by hormonal assays.

Subacute (granulomatous) thyroiditis ,Riedel's thyroiditis, suppurative thyroiditis :One case of each of these types was identified ( table1).

\section{Laboratory findings}

Thyroid function tests;

Assessment of T3, T4 and TSH was carried out preoperatively on 35 cases of thyroiditis irrespective of the specific type. The results show $37 \%$ euthyroid, $57 \%$ hyperthyroid, and $6 \%$ hypothyroid.
Serum autoantibody titers were qualitatively assessed by ELISA technique. Nine cases of the tested sera from 17 patients with proved FLT, have positive anti-Tg (53\%), 13 cases (76\%) have positive anti-Tpo, 3 cases $(17 \%)$ have positive AMA, and a single case $(6 \%)$ of the total 17 cases was positive for ANA. Four cases of H.T were tested by this assay and showed positive anti- Tg, anti - Tpo each in two cases. A single case was positive for anti- Tg, anti - Tpo, ANA and AMA.

Immunohistochemical technique;

For the first twelve cases of thyroiditis only, thyroglobulin monoclonal antibody marker was tested; they comprised 7 cases of H.T. and 5 cases of FLT. Strong immunoreactivity was identified in the follicular cells and Hürthle cells lining the atrophic follicles mainly in H.T., while in FLT, the staining was uniformly negative.

Figures (1-6) demonstrate gross and microscopical features of types of thyroiditis.

Table (1): Histopathological types of thyroiditis according to gender.

\begin{tabular}{|c|c|c|c|}
\hline Type & Number \% & Female & Male \\
\hline Hashimoto's thyroiditis & 31 & 30 & 1 \\
\hline Focal lymphocytic thyroiditis & & & 4 \\
\hline Grade I & 40 & 36 & 1 \\
\hline Grade II & 24 & 23 & 1 \\
\hline Grade III & 2 & 1 & 1 \\
\hline Subacute thyroiditis & 1 & 1 & 8 \\
\hline Riedel's thyroiditis & 1 & & \\
\hline Suppurative thyroiditis & 1 & 92 & \\
\hline Total & 100 & & \\
\hline
\end{tabular}

Table (2) : Pathological conditions associated with different types of thyroiditis.

\begin{tabular}{||c|c|c|c||}
\hline Type & Follicular adenoma & H.C. Tumor & Papillary Ca. \\
\hline \hline $\begin{array}{c}\text { - Hashimoto's thyroiditis } \\
5 / 31(16 \%)\end{array}$ & $1(3 \%)$ & $3(10 \%)$ & $1(3 \%)$ \\
\hline $\begin{array}{c}\text { - Focal lymphocytic thyroiditis } \\
11 / 66(16 \%)\end{array}$ & $6(9 \%)$ & $4(6 \%)$ & $1(1.5 \%)$ \\
\hline Grade I & 4 & 1 & 1 \\
\hline Grade II & 1 & 3 & \\
\hline Grade III & 1 & & \\
\hline \multicolumn{7}{|l|}{}
\end{tabular}


Table (3): Hashimoto's thyroiditis; comparative results of histopathological parameters and function (30 females and one male).

\begin{tabular}{|c|c|c|c|c|}
\hline Histologic parameter & No. and \% & $\begin{array}{l}\text { Euthyroid } \\
\end{array}$ & hyperthyroid & P. value \\
\hline $\begin{array}{l}\text { 1. lymphoid follicles } \\
\text { with germinal centre } \\
\text { without germinal centre }\end{array}$ & $\begin{array}{c}22(71 \%) \\
9(29 \%)\end{array}$ & $\begin{array}{l}17(77 \%) \\
7(77.7 \%)\end{array}$ & $\begin{array}{c}5(23 \%) \\
2(22.2 \%)\end{array}$ & N.S. \\
\hline $\begin{array}{l}\text { 2. Hürthlecell metaplasia } \\
\text { Diffuse } \\
\text { Focal }\end{array}$ & $\begin{array}{l}13(42 \%) \\
18(58 \%)\end{array}$ & $\begin{array}{c}8(62 \%) \\
16(89 \%)\end{array}$ & $\begin{array}{l}5(38 \%) \\
2(11 \%)\end{array}$ & N.S. \\
\hline $\begin{array}{l}\text { 3. Fibrosis } \\
\text { Mild } \\
\text { Moderate } \\
\text { severe } \\
\text { absent }\end{array}$ & $\begin{array}{c}15(48 \%) \\
12(39 \%) \\
3(10 \%) \\
1(3 \%)\end{array}$ & $\begin{array}{c}12(80 \%) \\
9(75 \%) \\
2(66.6 \%) \\
1\end{array}$ & $\begin{array}{c}3(20 \%) \\
3(25 \%) \\
1(33.4 \%)\end{array}$ & N.S. \\
\hline $\begin{array}{l}\text { 4hyroid follicles } \\
\text { of nontoxic type } \\
\text { of toxic type } \\
\text { mixed }\end{array}$ & $\begin{array}{c}23(74 \%) \\
4(13 \%) \\
4(13 \%)\end{array}$ & $\begin{array}{l}21(91 \%) \\
1(25 \%) \\
2(50 \%)\end{array}$ & $\begin{array}{l}2(9 \%) \\
3(75 \%) \\
2(50 \%)\end{array}$ & N.S. \\
\hline $\begin{array}{cc}\text { 5. Atrophic follicles } \\
\text { Present } \\
\text { Absent }\end{array}$ & $31(100 \%)$ & $24(77.5 \%)$ & $7(22.5 \%)$ & N.S. \\
\hline $\begin{array}{ll}\text { 6. } & \text { Plasma cells } \\
\text { Present } \\
\text { Absent }\end{array}$ & $\begin{array}{l}21(68 \%) \\
10(32 \%)\end{array}$ & $\begin{array}{c}20(95 \%) \\
4(40 \%)\end{array}$ & $\begin{array}{l}1(5 \%) \\
6(60 \%)\end{array}$ & $<0.05$ \\
\hline $\begin{array}{l}\text { 7. Giant cells } \\
\text { Present } \\
\text { Absent }\end{array}$ & $\begin{array}{c}2(6 \%) \\
29(94 \%)\end{array}$ & $\begin{array}{c}2 \\
22(76 \%)\end{array}$ & $7(24 \%)$ & N.S. \\
\hline
\end{tabular}

Table (4): Positive results of the qualitative assessment of serum autoantibody titer in patients with thyroiditis (Number of patients and percentages are in parenthesis).

\begin{tabular}{|c|c|c|c|c|c||}
\hline \hline Serum autoantibody type & $\begin{array}{c}\text { FLT } \\
\text { grade I(8) }\end{array}$ & $\begin{array}{c}\text { FLT } \\
\text { grade II(8) }\end{array}$ & $\begin{array}{c}\text { FLT } \\
\text { grade III(1) }\end{array}$ & FLT Total & $\begin{array}{c}\text { H.T. } \\
(4)\end{array}$ \\
\hline \hline Anti - Tg & $\mathbf{2 ( 2 5 \% )}$ & $\mathbf{7 ( 8 8 \% )}$ & $\mathbf{0}$ & $\mathbf{5 3 \%}$ & $\mathbf{2}$ \\
\hline Anti - Tpo & $\mathbf{4 ( 5 0 \% )}$ & $\mathbf{8 ( 1 0 0 \% )}$ & $\mathbf{1}$ & $\mathbf{7 6 . 5 \%}$ & $\mathbf{2}$ \\
\hline AMA & $\mathbf{1 ( 1 7 \% )}$ & $\mathbf{2 ( 2 5 \% )}$ & $\mathbf{0} \%$ & $\mathbf{1 7 . 5 \%}$ & 1 \\
\hline ANA & $\mathbf{0}$ & $\mathbf{1 ( 1 2 . 5 \% )}$ & $\mathbf{0}$ & $\mathbf{6 \%}$ & 2 \\
\hline
\end{tabular}
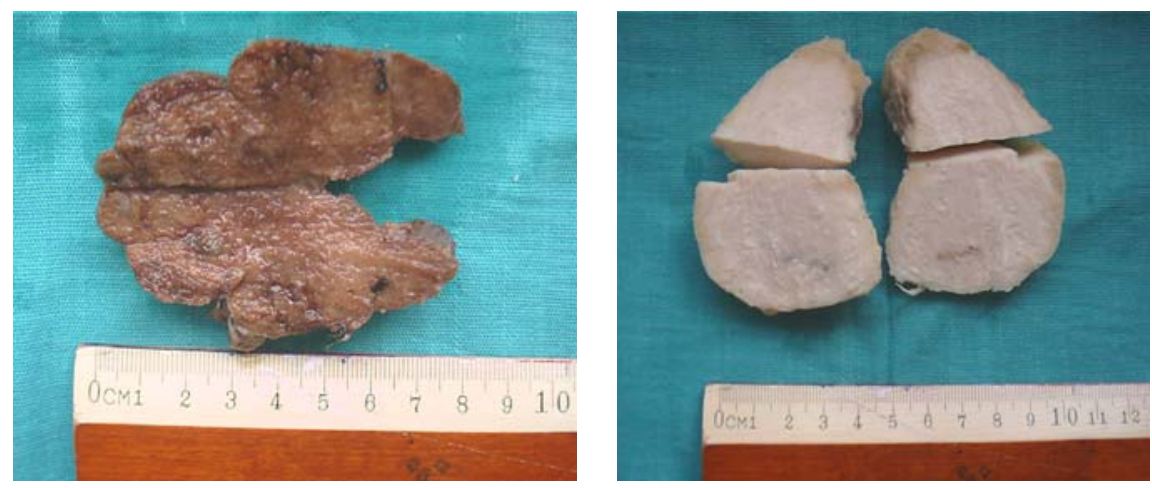

Figure (1)(Left ) Cut surface of a gland involved by diffuse variant of Hashimoto's thyroiditis (vaguely nodular surface).

Figure (2)(Right) Riedel's thyroiditis, non lobulated diffuse fibrotic cut surface with loss of normal thyroid appearance. 

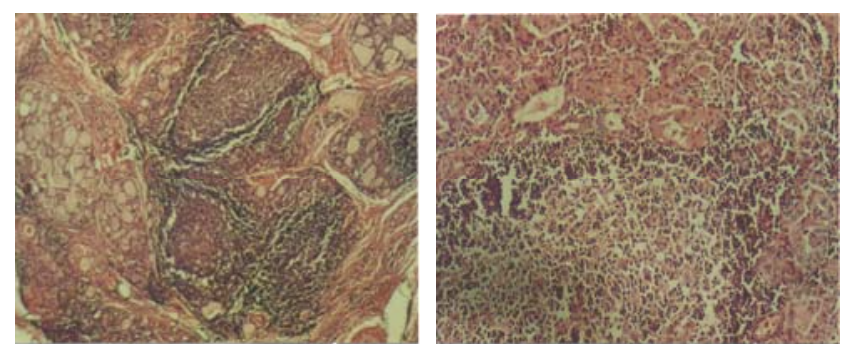

Figure (3)(Left) Hashimoto's thyroiditis, multiple germinal lymphoid follicles, bands of fibrous septa, and nontoxic colloid follicles (H\&E X 20). Figure (4)(Right) Hürthle cell metaplasia lining atrophic follicles in close proximity to a lymphoid follicle with germinal centre in a case of H.T. (H\&E X 40).

\section{Discussion:}

By using strict and well defined diagnostic criteria during a one year period, we tried to identify and analyse the frequency and the significance of thyroiditis amongest 298 thyroidectomy specimens performed in Mosul city; a locality which is endemic with goitre.

Unspecified thyroiditis was observed in $33.5 \%$ of the cases, which is close to results reported by others; namely $(40 \%$ Carcangiu and DeLellis $96^{(1)} ; 30 \%$ Moosa and Mozzaferri $98^{(6)}$; and 26\% Livolsi $94^{(2)}$ ).

In thyroiditis, female predominance is pronounced with a F:M ratio of 11.5:1. Similar observation has been reported by others $^{(1,7-11)}$. The mean age was 35 years. Similar age incidences were observed by other authors ${ }^{(1,7,8,10,11)}$.

\section{Hashimoto's thyroiditis}

Thirty one cases with H.T. were seen in this study, accounted for $10.4 \%$ of all thyroid disorders in Mosul. This frequency is close to or similar to the ratio observed by others as demonstrated in the comparative table below;

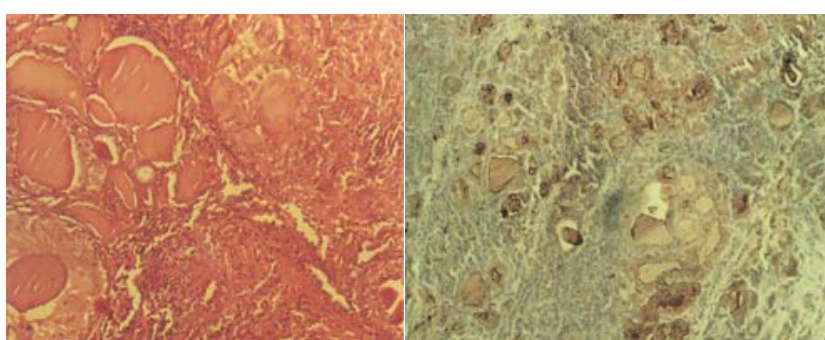

Figure (5)(Left) Granulomatous thyroiditis with colloid containing giant cells (H\&E X40).

Figure (6)(Right) Strong immunoreactivity for thyroglobulin in cells lining atrophic follicles in a case of Hashimoto's thyroiditis (immunoperoxidase stain X40) .

The condition predominates in females with $\mathrm{F}: \mathrm{M}$ ratio of $30: 1$; This is consistent with another study ${ }^{(2)}$. The mean age is 38 years, similar to age distribution as described by others $^{(1,2,3,6)}$. Clinically, the majority of the patients (80\%) were euthyroid at presentation. This is similar to the findings observed by others ${ }^{(1,2,3,6,11-15)}$, and is consistent with the usual clinical course of H.T. where thyroid function progresses from overactive to normal and ending up in hypothyroid state $e^{(1,2,3)}$. Grossly thyroidectomy specimens had the patterns expected in H.T. ${ }^{(1-3,6,13)}$, which were either nodular and fibrosing (64\%) or diffuse (36\%). Sporadic cases show additional features including: follicular adenoma (one case), H.C. adenoma (three cases) and papillary carcinoma in a single case. Follicular adenoma is a lesion common to the thyroid and can be seen in association with every type of thyroid disorders ${ }^{(16)}$. The latter two conditions might be considered as complications of H.T..$^{(3,17,18)}$ or incidental findings.

\begin{tabular}{|c|c|c|c|c|c|}
\hline Thyroid disorder & $\begin{array}{c}\text { Mossa and } \\
\text { Mozzaferri } 98^{(6)}\end{array}$ & $\begin{array}{c}\text { Gardiner and } \\
\text { Russell 95 }^{(8)}\end{array}$ & $\begin{array}{c}\text { McKee et al } \\
\mathbf{9 5}^{(9)}\end{array}$ & Thanoon 93 $^{(10)}$ & Current study \\
\hline \hline H.T. & $10 \%$ & $4 \%$ & $6 \%$ & $7 \%$ & $10.4 \%$ \\
\hline
\end{tabular}




\section{Microscopically:}

Thyroid follicular cells, were of the nontoxic simple type in $74 \%$ and normal function in $92 \%$, or of the toxic hyperplastic type with thin absorbed colloid, which was directly related to the function of the thyroid as assessed by TFT. Thus, in $75 \%$ of cases with toxic goitre, the follicular cells were either of the toxic or the mixed type.

Hürthle cells, diffuse H.C. change was observed in $42 \%$ of the cases. In the rest, it was multifocal (58\%). Hyperthyroidism was observed in $38 \%$ of those with diffuse H.C. change, so it is possible, that change from focal to diffuse follows the progression of the disease ${ }^{(1-4)}$, although the concordance between the degree of metaplasia and the function is not total and the majority of patients were euthyroid $(77.5 \%)$ with $\mathrm{P}$ - value $>0.05$. All cases of H.T. have small atrophic follicles, often lined by Hürthle cells, the majority of these cases $(77.5 \%)$ have normal thyroid function, this was similar to that recognized by others $^{(1,2)}$. However, the number of the thyroid follicles (whether toxic, nontoxic, or mixed ) decreased among the remaining atrophic follicles ${ }^{(1,3)}$.

The fibrosing variant of H.T. was observed in 3 cases (10\%). This type shows accentuated fibrosis and is seen in $10-12 \%$ of cases of H.T. as described by others ${ }^{(1,3)}$. There was no obvious correlation with the function as 2 out of 3 cases were euthyroid ( $p$ value $>0.05$ ). The degree of lymphocytic infiltration was variable. However in $71 \%$ of the cases, it was intense with germinal centres. Similar observation was made by others ${ }^{(3,6,13,19)}$. No significant correlation was noticed between the lymphocytic infiltration and the thyroid function since $74.5 \%$ of the cases were euthyroid.

Plasma cells, were identified in 21 cases (71\%), recognized mainly in fibrosing variant as stated in previous studies ${ }^{(1,3)}$. Giant cells; are sparse in H.T. and in this study were observed in 2 cases only, both of which were euthyroid. These cells are known to occur in intrafollicular location ${ }^{(3,20)}$.

\section{Focal lymphocytic thyroiditis:}

It forms $22 \%$ of all thyroid disorders in this study, It is within the ratio of $22-40 \%$ and a female preponderance (F:M ratio of 10-20:1) as recognized by others ${ }^{(1,2,3,6,21,22)}$.

The age incidence was 30-50 years with a mean age of 37 years. There is no apparent significant relationship between the degree of lymphocytic infiltration and the age incidence as noticed also by Mitchell and Kirkham $84^{(21)}$.

Thyroid function tests were available for 28 out of 66 cases of FLT, 15 (53\%) were hyperthyroid, 11 (39\%) were euthyroid and the remaining two cases (7.3\%) were hypothyroid. Similar variation in thyroid function has been described by others ${ }^{(1,7,22)}$.

\section{Microscopically}

Follicular cells, are predominantly of the simple nontoxic type with abundant colloid. This feature was matched by euthyroid in $62 \%$ of the cases with an exception of 2 cases with grade III whose thyroid function showed overactivity irrespective of the follicular lining by simple (nontoxic) epithelium. Foci of Hürthle cells were noticed in 6 cases, most of which were euthyroid. Similar observation was made by others ${ }^{(3,19,22)}$.

Atrophic follicles were seen in $42 \%$ of the cases of grade II and III, but in only $4 \%$ of grade I which is similar to the results made by Greenberg et al $70^{(22)}$. However, statistical analysis of the correlation between the type of the follicular epithelium and the thyroid function was not significant ( $P$ value $>0.05$ ).

Fibrosis was scanty in $57.6 \%$ of the cases. A single case of grade I showed marked degree of fibrosis and was also euthyroid. A similar case with severe fibrosis has been reported by Greenberg et al $70^{(22)}$ from a collection of 30 cases.

Lymphocytic infiltration, was categorized into 3 grades according to its intensity ${ }^{(2)}$. In the majority of cases, lymphoid aggregates devoid of germinal centres are the main type, particularly in grades I and II (98\% and $71 \%$ respectively). However germinal centres were observed in the remainder and were abundant in grade III. Rosai $96^{(3)}$ and Livolsi and Merino $81^{(19)}$ also described similar results.

Plasma cells, were absent from the inflammatory infiltrate in $88 \%$ of the cases. This was unlike the infiltrate in H.T. which invariably contains a number of plasma cells, it 
appears that the immunological response is more intense in H.T. than in FLT, although hypothyroidism is likely to occur in the latter following thyroidectomy ${ }^{(3,7)}$.

\section{Antibodies in thyroiditis:}

Qualitative assessment of serum anti-Tg and anti- Tpo was available for only 4 patients with H.T. The results show equal distribution for positivity with 2 cases in each category viz; anti-Tg and anti-Tpo. The number is too small to be of any significance, however studies on larger scales had shown variable results for each of the 2 antibodies as illustrated in the table below:

\begin{tabular}{||l|l|l||}
\hline Study & Anti- Tg & Anti-Tpo \\
\hline $\begin{array}{l}\text { Walter and Tulbot } \\
\mathbf{9 6}^{(23)}\end{array}$ & $45 \%$ & $90 \%$ \\
\hline $\begin{array}{l}\text { Dayan and Daniels 96 } \\
\text { (24) }\end{array}$ & $60 \%$ & $95 \%$ \\
\hline $\begin{array}{l}\text { Estienne et al 99(25) } \\
(437 \text { cases of H.T.) }\end{array}$ & $40 \%$ & $40 \%$ \\
\hline $\begin{array}{l}\text { Zophel et al 99 } \\
(36)\end{array}$ & $61 \%$ & $61 \%$ \\
\hline $\begin{array}{l}\text { Current study } \\
\text { (4 cases })\end{array}$ & $50 \%$ & $50 \%$ \\
\hline
\end{tabular}

As for FLT, the number of cases assessed was more (17cases) but includes all grades of lymphocytic infiltrates. Anti-Tg was positive in about half of the cases (53\%) while Anti-Tpo was positive in almost $2 / 3^{\text {rd }}$ of them (76.5\%). Patients with grade II FLT show 100\% positivity for Anti-Tpo, while only $50 \%$ of patients with grade I were positive for the same test. Again ,the number of cases is of little calibre to be of definitive significance, however, it does support the suggestion made by others ${ }^{(1,3,6)}$, that FLT may have an autoimmune pathogenetic mechanism with a good and definite correlation between the degree of lymphocytic infiltration and the titre of Anti $-\mathrm{Tpo}^{(27)}$ and as illustrated below:

\begin{tabular}{|l|l|l|l||}
\hline Study & $\begin{array}{l}\text { No. of } \\
\text { patients }\end{array}$ & Anti-Tg & Anti-Tpo \\
\hline \hline Tanner et al 82 $^{(28)}$ & 63 & $36.5 \%$ & $95 \%$ \\
\hline \hline Grubeck et al 86 $^{(29)}$ & 20 & $35 \%$ & $50 \%$ \\
\hline \hline Zophel et al 99 $^{(26)}$ & 28 & $64 \%$ & $64 \%$ \\
\hline \hline Current study & 17 & $53 \%$ & $76.5 \%$ \\
\hline
\end{tabular}

Antimitochondrial antibody, was assessed in the sera of the same group of patients above. The titer was positive in $1 / 4$ cases of H.T. and $3 / 17$ cases of FLT. This antibody is shared with other autoimmune conditions specifically primary biliary cirrhosis ${ }^{(30,31)}$ and the two conditions are known to coexist ${ }^{(32,33)}$.Antinuclear antibody, was positive in $2 / 4$ cases of H.T. and $1 / 17$ cases of FLT which was of grade II. It has been recognized that patients in whom ANA is positive, tend to express Anti-Tpo more frequently than in those with negative $A N A^{(34)}$. Shibasaki et al $90^{(35)}$ and Sato et al $99^{(36)}$, reported a single case, each of H.T. associated with primary biliary cirrhosis in whom the ANA and AMA were positive. In our group of 4 patients with H.T. assessed for AMA and ANA, a single case was positive for both. However, the patient was not clinically known to have any features of cirrhosis.

In summary and irrespective of the small number of cases, the presence of autoantibody in over half of the cases of H.T. and FLT tested, is concordant with the concept of autoimmune pathogenesis for both diseases $^{(1,23,37)}$.

Immunohistochemical staining for thyroglobulin, expressed strong positive reaction mainly in the atrophic follicles which are lined mainly by Hürthle cells. This is concordant with the observation made by Carcangiu and DeLellis $96^{(1)}$. However, considering the high cost of this technique, it can hardly be recommended as a marker for H.T.

\section{References:}

1. Carcangiu M.R. and DeLellis R.A. (1996). Thyroid gland (chapter 61). In: Carcangiu and DeLellis. Anderson's Textbook of Pathology $\left(10^{\text {th }}\right.$ edition). Mosby, New York, ,pp 1947-1955.

2. Livolsi V.A.(1994). Thyroid and parathyroid (chapter 12). In: Sternberg S.S. Diagnostic Surgical Pathology (2 $2^{\text {nd }}$ edition). Raven press, New York, PP 523-559.

3. Rosai J. (1996). Thyroid gland (chapter 9). In: Ackerman's Surgical Pathology $\left(8^{\text {th }}\right.$ edition). Mosby, New York, PP 493-568. 
4. Wilson and Daniel W.F. (1985).Thyroid gland. In: Wilson and Daniel W.F. Textbook of Endocrinology ( $7^{\text {th }}$ edition). W.B.Saunder's company, Dallas-Texas, pp 806-810.

5. MacSween R.N.M and Whaley K.(1995). Endocrine pathology-thyroid gland (chapter 23). In: Muir's Textbook of Pathology ( $13^{\text {th }}$ edition). Arnold, New York, pp 1084 -1096.

6. Moosa M. and Mozzaferri E.L. (1998). Disorders of the thyroid gland (chapter 129). In: Cummings C.W., Fredrickson J.M., Harker L.A., et al. Otolaryngology Head and Neck Surgery ( $3^{\text {rd }}$ edition). Mosby, St. Louis .Missouri, pp 2450-2479.

7. Hargreaves A.W., Garner A. The Significance of lymphocytic infiltration of the thyroid gland in thyrotoxicosis. British Journal of Surgery. (1968); 55:543-545.

8. Gardiner and Russell Thyroidectomy for large Multinodular colloid goitre. J.R. Coll. Surg. Edinb. (1995); 40: 367-370.

9. McKee G,. Asimakopoulos G, Loosemore $\mathrm{T}$., et al A regional study of thyroidectomy: Surgical pathology Suggests scope to improve quality and reduce cost. Ann. R. Coll. Surg. Engl. (1995); 77: 425-430.

10.Thanoon S. (1993); Thyroid masses, A clinico pathological study in Mosul, MSc thesis, College of Medicine, Department of Pathology, Mosul University . P 80.

11.Roth C., Scortea M., Stubbe, et al Autoimmune thyroiditis in childhood, epidemiology, clinical and laboratory findings in 61 patients. Exp. Clin .Endocrinol. Diabetes. (1997); 4(105):6669 (Abstract).

12.Gluck F.B., Nusynowitz M.L. and Plymate S. Chronic Lymphocytic Thyroiditis, thyrotoxicosis and low radioactive iodine uptake. New Engl J Med. (1975); 293 : $624-628$.

13.Zimmerman R.S., Brennan M.D., Mc Conahey W.M., et al Hashimoto's thyroiditis, an uncommon cause of painful thyroid unresponsiveness to corticosteroid therapy. Annals of Internal Medicine. (1986); 104: 355 - 357.
14.Scherbaum W.A., Stockle G., Wichmann J., et al Immunological and clinical characterization of patients with untreated euthyroid and hypothyroid autoimmune thyroiditis. Antibody spectrum, response to $\mathrm{TRH}$ and clinical study. Acta Endocrinologica. (1982); 100; 373-381.

15. Nabeel I., Waheed A.S. Thyrotoxicosis in Qatar. The Journal of Arab Board of Medical Specializations. (1999); 1(2): 8587.

16. Hung W. Solitory thyroid nodules in 93 children and adolescents, a 35 years experience. Horm. Res. (1999); 52(1): 1518 (Abstract).

17. Holm L.E., Blomgren $H_{\text {., }}$ löwhagen $T$. Cancer risks in patients with chronic lymphocytic thyroiditis. New Engl J Med. (1985); 312(10): 601-604.

18.Loh K.C., Greenspan, Dong, et al Influence of lymphocytic thyroiditis on the prognostic outcome of patients with papillary Carcinoma. J. Clin. Endocrinol. Metab. (1999); 84(2): 458-463 (Abstract).

19.Livolsi V.A. and Merino M.J. (1981). Histopathologic Differential Diagnosis of The Thyroid. Pathology Annual. 16(2): 385-396.

20.Kneckt H., Hedinger C.E. Ultrastructural findings in Hashimoto's thyroiditis and focal lymphocytic thyroiditis with reference to giant cell formation. Acta Endocrinologica. (1982); 6: 511 - 538.

21. Mitchell J.D., Kirkham N. Focal lymphocytic thyroiditis in Southampton. Journal of Pathology. (1984); 144:269-273.

22.Greenberg A.H. ,Czernichow p., Hung W., et al Juvenile chronic lymphocytic thyroiditis: clinical and laboratory and histological correlations. J. Clin. Endocrin. Metab. (1970); 30(3) : 293-301.

23.Walter J.B., Tulbot I.C. Immunopathogenesis (chapter 13) organ specific autoimmune diseases. In: Walter and Israel General Pathology, $7^{\text {th }}$ edition. Churchill Livingstone, Edinburgh, (1996); P 245.

24.Dayan C.M., Daniels G.H. Chronic autoimmune thyroiditis. New Engl J Med. (1996); 335(2): $99-106$. 
25.Estienne V., Duthoit C., Costanzo V.D., et al Multicenter study on TGPO autoantibody prevalence in various thyroid and non thyroid diseases; relationship with thyroglobulin and thyroperoxidase autoantibody parameters. Eur. J. Endocrinol. (1999); 141(6); 563-569 (Abstract)

26.Zophel K., Gruning T., Wunderlich G., et al Clinical value of biphasic antibody binding to thyroglobulin and thyroperoxidase (TGPO - $a A b)$ in various thyroid diseases. Autoimmunity. (1999); 29(4): 257 - 262 (Abstract).

27.Inukai T., and Takemura Y. Antithyroid Peroxidase Antibody. Nippon - Rinsho. (1999); 57(8): 1819 - 1823(Abstract).

28.Tanner A.R., Scottmorgan L., Mardell, et al The incidence of occult thyroid disease associated with thyroid antibodies identified on Routine screening. Acta Endocrinologica. (1982); 100: 31 - 35.

29.Loebenstein B.G., Kassal H., Smyth P.P., et al The prevalence of immunological abnormalities in endemic goitre. Acta Endocrinologica (Copenh). (1986); 113: $508-513$

30.Zhong L., Weetman A.P., Jayene D.R., et al Antimitochondrial antibody IgG subclass distribution and affinity in primary biliary Cirrhosis. Clin. Exp. Immunol. (1992); 88(1); 56-61 (Abstract).

31. Kaplan et al. Primary biliary cirrhosis. New Engl J Med. (1987); 316: 521 - 529.
32.Rajaraman S., Deodhar S.D., carey W.D., et al. Hashimoto's thyroiditis, primary biliary cirrhosis and myasthenia gravis. Am. J. Cl. Pathol. (1980); 74: 831 - 834.

33.Marino M., Ricciardi R., Pinchera A., et al Mild clinical expression of myasthenia gravis associated with autoimmune thyroid disease. J. Clin. Endocrinol. Metab. (1997); 82: $438-443$.

34.Reyes H., Peter J.B. Frequency of biochemical hypothyroidism in sera referred for autoantibody testing. Clin. Diagn. Lab. Immunol. (1994); 1(3): 351 352 (Abstract).

35.Shibasaki T., Shimada T., Morita T., et al Immunological penetrance in patients with primary biliary cirrhosis. Jpn. J. Med. (1990); 29(5): 533 - 536 (Abstract).

36. Sato N., Chiro $H_{\text {., }}$ Orikasa $H_{\text {., }}$ et al. Primary biliary cirrhosis associated with painless thyroiditis. Intern. Med. (1999); 38(3): 244 - 248(Abstract).

37.Gardas A., Rives K.L. Enzyme linked immunosorbent assay of autoantibodies reacting with thyroid plasma membrane antigens in sera of patients with autoimmune thyroid disease. Acta Endocrinologica (Copenh). (1986); 113: $255-260$ 